\title{
Implementasi Pembelajaran Daring dalam Mata Pelajaran Matematika Materi Pengukuran Sudut
}

Received:

$11 / 12 / 2021$

Accepted:

$17 / 12 / 2021$

Published: $1 / 3 / 2022$

\author{
${ }^{1}$ Muhlis, ${ }^{2}$ Umi Isroul Mahmudah, ${ }^{3}$ Sukriadi \\ Universitas Mulawarman, Samarinda, Indonesia \\ 1muchlisart17@gmail.com
}

\begin{abstract}
This research is motivated by the mathematics learning of angle measurement material which is carried out online due to the covid-19 pandemic so that mathematics learning which should be studied intensively with face-to-face learning so that students more easily understand this material cannot be carried out due to the covid-19 pandemic which resulted in learning mathematics is not optimal. This study aims to determine the preparation of teachers in implementing online learning, to determine the implementation of online learning on angle measurement material, and to determine the supporting and inhibiting factors in applying online learning to angle measurement material in class IV SDN 007 Sungai Kunjang. The results showed that the teacher had carried out online learning of angle measurement material with good preparation. The application of online learning of angle measurement material went well with obstacles that the teacher could overcome. The supporting factors for online learning are devices and adequate internet quotas and the inhibiting factor for online learning is not having a device and internet quota. Based on the results of the research above, it can be concluded that teacher preparation in carrying out online learning plays a major role in achieving learning objectives and adequate learning facilities will make it easier for students to carry out online learning of this angle measurement material.
\end{abstract}

Keywords: Angle Measurement, Implementation Online Learning, Mathematics 
dalam melaksanakan pembelajaran daring berperan besar untuk mencapai tujuan pembelajaran dan fasilitas pembelajaran yang memadai akan mempermudah siswa untuk melaksanakan pembelajaran daring materi pengukuran sudut ini..

Kata kunci: Matematika, Penerapan Pembelajaran Online, Pengukuran Sudut.

\section{Pendahuluan}

Penerapan pembelajaran dari rumah secara daring menuntut para guru untuk lebih inovatif dalam menyusun langkah-langkah pembelajaran agar pembelajaran daring dapat memotivasi peserta didik agar giat dalam belajar (Vortunata et al., 2020). Peran orang tua dalam pembelajaran daring sangat penting, terlebih bahan ajar yang hanya dikirim dalam bentuk power point, microsoft word, video pembelajaran atau dalam bentuk gambar yang kemudian peserta didik dalam pendampingan orang tua diharuskan untuk memahami sendiri. Kondisi orang tua yang berbeda-beda menjadikan output yang dihasilkan para peserta didik juga berbeda-beda, namun peserta didik dituntut paham sama seperti saat melakukan suatu pembelajaran tatap muka agar hasil belajar yang diperoleh tetap baik sama halnya seperti sebelum pandemi.

Kondisi pandemi ini mewajibkan para orang tua agar mampu memotivasi peserta didik agar tetap semangat belajar dan mampu mendampinginya dalam kegiatan pembelajaran (Mustakim, 2020; Syarifudin, 2020). Namun, tidak semua orang tua peserta didik ini dapat membimbing anaknya dalam suatu pembelajaran terutama dalam pembelajaran matematika dikarenakan tidak memahami serta tidak menguasai suatu materi pembelajaran matematika, ini disebabkan pembelajaran matematika dianggap sulit oleh sebagian besar orang tua. Sedangkan peserta didik sebagian besar sangat memerlukan bimbingan dan arahan mereka agar dapat memahami dan menguasai materi pembelajaran yang ada di buku dan mampu mengerjakan tugas-tugas yang diberikan oleh guru dengan baik (Safitri, 2019; A. Wiratman et al., 2019). Oleh karena itu, orang tua peserta didik di masa pandemi ini dituntut untuk aktif serta ikut memahami materi pembelajaran yang akan dipelajari. Banyaknya berbagai permasalahan lain yang sering timbul selama pembelajaran daring seperti kurangnya sarana dan prasarana yang mendukung terjadinya pembelajaran seperti tidak mampu memiliki ponsel android ataupun tidak memiliki kuota dikarenakan keadaan ekonomi serta adanya gangguan jaringan menjadikan pembelajaran daring ini tidak sepenuhnya efektif untuk dijalankan.

Penerapan pembelajaran daring khususnya dalam mata pelajaran matematika dapat berlangsung dengan baik jika motivasi belajar pada siswa tinggi, hal ini dikarenakan mata pelajaran ini lebih sulit untuk dipahami oleh siswa dibandingkan dengan mata pelajaran lain (Wiratman et al., 2021). Dengan adanya penelitian ini, peneliti bertujuan agar masalah yang terjadi pada siswa yang mengalami kesulitan memahami materi matematika pada pembelajaran daring ini dapat teratasi dan siswa dapat memahami materi matematika khususnya materi pengukuran sudut dengan mudah serta dapat mengerjakan tugas dan ujian matematika dengan mudah tanpa adanya kendala.

Penerapan pembelajaran daring pada mata pelajaran matematika materi pengukuran sudut ini memerlukan media (aplikasi) yang sesuai dan sarana yang memadai agar siswa 
dapat memahami secara baik akan materi yang disampaikan oleh guru dan dapat mempraktekkan secara langsung bagaimana cara mengukur sudut yang benar. Siswa juga harus aktif untuk mencari berbagai alternatif sumber materi agar dapat memahami dan mempraktekkan cara mengukur sudut. Guru sangat berperan besar terhadap pemahaman siswa dan siswa juga harus aktif bertanya kepada guru jika ada hal-hal yang kurang dipahami.

\section{Metode Penelitian}

Metode penelitian yang digunakan dalam penelitian ini adalah penelitian kualitatif. Penelitian ini menggunakan teknik pengumpulan data berupa wawancara, observasi, dan dokumentasi. Teknik analisis data yang dilaksanakan dalam penelitian ini adalah reduksi data, penyajian data, dan penarikan kesimpulan/verifikasi (Sugiyono, 2017).

Berikut ini kisi-kisi pedoman wawancara guru untuk mengetahui implementasi pembelajaran daring dalam mata pelajaran matematika materi pengukuran sudut kelas IV SDN 007 Sungai Kunjang :

\begin{tabular}{|c|c|c|c|}
\hline No. & Indikator & Sub Indikator & $\begin{array}{l}\text { No. Butir } \\
\text { Pertanyaan }\end{array}$ \\
\hline \multirow[t]{9}{*}{1.} & \multirow{9}{*}{$\begin{array}{l}\text { Penerapan } \\
\text { Pembelajaran } \\
\text { Daring pada Siswa } \\
\text { Kelas IV }\end{array}$} & $\begin{array}{l}\text { Persiapan guru dalam penerapan pembelajaran } \\
\text { daring }\end{array}$ & 1 \\
\hline & & Penerapan pembelajaran daring sesuai & 2 \\
\hline & & $\begin{array}{l}\text { ketentuan prosedur standar pendidikan yang } \\
\text { berlaku }\end{array}$ & \\
\hline & & Tata cara pembelajaran daring & 3 \\
\hline & & $\begin{array}{l}\text { Keaktifan peserta didik dalam pembelajaran } \\
\text { daring }\end{array}$ & 4 \\
\hline & & $\begin{array}{l}\text { Aplikasi yang digunakan dalam pembelajaran } \\
\text { daring }\end{array}$ & 5 \\
\hline & & $\begin{array}{l}\text { Kesesuaian media dengan materi pengukuran } \\
\text { sudut }\end{array}$ & 6 \\
\hline & & $\begin{array}{l}\text { Tingkat pemahaman siswa menerapkan } \\
\text { pembelajaran daring dalam materi pengukuran } \\
\text { sudut }\end{array}$ & 7 \\
\hline & & $\begin{array}{l}\text { Tingkat Kesulitan Penerapan pembelajaran } \\
\text { daring matematika dibandingkan mata pelajaran } \\
\text { lainnya }\end{array}$ & 8 \\
\hline \multirow[t]{4}{*}{2.} & \multirow{4}{*}{$\begin{array}{l}\text { Faktor pendukung } \\
\text { dan penghambat } \\
\text { dari penerapan } \\
\text { pembelajaran } \\
\text { daring pada mata } \\
\text { pelajaran } \\
\text { matematika materi } \\
\text { pengukuran sudut }\end{array}$} & Faktor pendukung dan penghambat & 9 \\
\hline & & $\begin{array}{l}\text { Kendala alat, media, dan fasilitas dalam } \\
\text { menerapkan pembelajaran daring pada mata } \\
\text { pelajaran matematika materi pengukuran sudut }\end{array}$ & $10,11,12$ \\
\hline & & $\begin{array}{l}\text { Kendala guru dalam menerapkan pembelajaran } \\
\text { daring pada mata pelajaran matematika materi } \\
\text { pengukuran sudut }\end{array}$ & 13,14 \\
\hline & & $\begin{array}{l}\text { Solusi guru dalam menghadapi kendala dalam } \\
\text { menerapkan pembelajaran daring pada mata } \\
\text { pelajaran matematika materi pengukuran sudut }\end{array}$ & $15,16,17,18,19$ \\
\hline
\end{tabular}




\section{Hasil}

\section{Implementasi Pembelajaran Jarak Jauh (Daring) dalam Mata Pelajaran Matematika Materi Pengukuran Sudut}

Pembelajaran yang dilaksanakan di SDN 007 Sungai Kunjang Kota Samarinda pada masa pandemi covid-19 adalah pembelajaran jarak jauh (daring). Pembelajaran daring ini telah dilaksanakan dari bulan Maret 2020 hingga saat ini. Penerapan pembelajaran daring di sekolah ini telah sesuai dengan ketentuan prosedur standar pendidikan yang berlaku. Pembelajaran daring dilaksanakan sesuai anjuran pemerintahan untuk memutuskan dan menghambat penyebaran virus covid-19.

Pelaksanaan pembelajaran daring memerlukan persiapan guru yang baik agar pembelajaran berlangsung dengan lancar. Guru melakukan persiapan pembelajaran daring dengan membuat RPP yang sesuai dengan keadaan saat ini, menentukan jenis media (aplikasi) yang sesuai dengan materi yang akan diajarkan agar mempermudah pemahaman siswa akan materi yang disampaikan, membuat pembelajaran yang terencana dengan penyampaian materi secara jelas dan singkat dikarenakan keterbatasan waktu dan kuota internet, menyiapkan tugas yang harus dikerjakan siswa dengan batas waktu pengumpulan dan memberikan kesempatan siswa untuk selalu bertanya, dan mengikuti pelatihanpelatihan daring untuk mendukung keterampilan guru dalam melaksanakan pembelajaran jarak jauh (daring). Persiapan guru SDN 007 Sungai Kunjang dalam melaksanakan pembelajaran daring ini telah sesuai dengan Surat Edaran Nomor 15 Tahun 2020 tentang Pedoman Penyelenggaraan Belajar Dari Rumah Dalam Masa Darurat Penyebaran Corona Virus Disease (COVID-19) Bab II Panduan Pelaksanaan Pembelajaran Dari Rumah.

Pelaksanaan pembelajaran daring di SDN 007 Sungai Kunjang ini dilaksanakan sesuai dengan Surat Edaran Nomor 15 Tahun 2020 yaitu dalam pelaksanaannya guru menyiapkan nomor-nomor telepon orang tua atau wali peserta didik dan membuat grup whatsapp, mendiskusikan kepada orang tua tentang ketersediaan gawai, dan saat pembelajaran guru selalu memeriksa kehadiran siswa, mengajak siswa untuk selalu berdoa sebelum dan sesudah pembelajaran, penyampaian materi, dan selalu memberikan kesempatan siswa untuk selalu bertanya dan mengemukakan pendapat.

Pembelajaran daring pada mata pelajaran matematika materi pengukuran sudut ini dilaksanakan dengan tata cara yaitu video call melalui whatsapp atau google meet ataupun pembagian video pembelajaran dan pembagian tugas di whatsapp grup atau google form. Pembelajaran daring pada mata pelajaran matematika materi pengukuran sudut ini memanfaatkan berbagai media (aplikasi) untuk mendukung pemahaman siswa seperti whatsapp, google form, google meet, dan classroom, seperti yang sudah dipaparkan oleh peneliti dengan guru-guru kelas IV dari kelas IV A (M. Hatta, S.Sos.I), IV B (Iswardeli, S.Pd), dan IV C (Siti Komariyah, S.Pd) sebagai berikut :

"Pembelajaran daring dilaksanakan melalui aplikasi whatsapp dan zoom. Saya lebih banyak mengajar melalui grup whatsapp. Untuk materi pengukuran sudut sendiri saya menggunakan whatsapp fitur video call. Untuk pelaksanaannya sama seperti pembelajaran tatap muka hanya 
saja salam, absensi, dan kegiatan pembelajaran hanya melalui ketikan yang tertuju kepada siswa dalam grup whatsapp". (MH, 28 April 2021)."

"Guru memberikan tugas melalui whatsapp grup kelas dan membagikan video pembelajaran kepada siswa melalui grup kelas. Siswa-siswa mengerjakan tugas sesuai tugas yang telah kami berikan, jadi siswa melaksanakan tugas bisa melalui video call atau mengumpulkan tugas melalui chat whatsapp". (I, 27 April 2021)

"Tata caranya itu ibu menggunakan gawai dan menggunakan aplikasi whatsapp, google form, google meet, dan google classroom. Untuk konsultasi diganti dengan whatsapp. Untuk materi pengukuran sudut ibu menggunakan aplikasi whatsapp dan google meet. Pengumpulan tugas setiap bab baru dikumpul langsung ke sekolah. Untuk melaksanakan pembelajaran daring guru sebenarnya harus inovatif agar siswa tidak jenuh dalam belajar". (SK, 28 April 2021)

Pembelajaran daring pada umumnya di semua mata pelajaran yang dijalankan oleh guru kelas IV menggunakan media (aplikasi) berupa whatsapp, zoom, youtube, google form, google meet, dan google classroom.

Keaktifan siswa kelas IV SDN 007 Sungai Kunjang dalam melaksanakan pembelajaran daring pada mata pelajaran matematika ini sudah sesuai dengan keinginan guru. Siswa aktif dalam bertanya dan hampir keseluruhan siswa selalu mengikuti pembelajaran.

"Hampir semua peserta didik sekitar 90\% aktif dalam menerapkan pembelajaran daring. Tetapi memang ada beberapa orang peserta didik yang tidak dapat mengikuti pembelajaran daring dikarenakan tidak ada handphone". (MH, 28 April 2021)

"Peserta didik selama pandemi ini aktif dalam menerapkan pembelajaran daring. Peserta didik telah sesuai dengan harapan guru mengerjakan tugas-tugas yang diberikan dengan baik, dan juga jika ada kesulitan siswa tidak segan untuk bertanya kepada guru". (I, 27 April 2021)

"Untuk keaktifan siswa, semua siswa aktif hanya saja saat zoom meeting tidak semuanya bisa hadir 100\%. Di kelas ini ada 31 orang siswa, yang bisa hadir 29 orang saat zoom meeting". (SK, 28 April 2021)

Pemahaman siswa dalam menerapkan pembelajaran daring materi pengukuran sudut ini sebagian ada yang memahami jika kemampuannya di atas rata-rata. Sedangkan jika daya serap siswa rendah maka akan sulit bagi siswa untuk memahami materi (Arif \& Iskandar, 2018; Novitasari, 2016). Jika dibandingkan pembelajaran dengan luring, daring dirasakan oleh siswa lebih sulit untuk memahami materi karena tidak diajarkan secara langsung. Pembelajaran daring dalam materi pengukuran sudut ini membuat siswa tidak keseluruhan dari mereka memahami materi. Sehingga setelah pembelajaran telah selesai diajarkan dan sesi pembelajaran ditutup masih ada beberapa siswa yang belum paham dan kembali bertanya kepada guru. Guru selalu siap sedia membimbing siswa yang merasa kesulitan di materi pengukuran sudut ini. Hal yang terpenting dalam pembelajaran daring ini siswa semangat dan selalu ingin bertanya setiap ada kesulitan sehingga target pembelajaran akan terpenuhi dengan baik. 
"Hampir semua siswa bisa saja memahami materi pengukuran sudut. Tetapi memang tidak semuanya bisa memahami melalui pembelajaran daring. Jadi sehabis pembelajaran siswa bisa bertanya kembali kepada saya hingga mereka bisa lebih memahami. Jika dibandingkan dengan pembelajaran luring, tentu saja luring lebih membuat siswa mudah memahami materi pengukuran sudut ini tetapi karena keadaan pandemi ini, kita memang harus menjalani sesuai ketentuan pemerintah yaitu menerapkan pembelajaran daring. Jika untuk hasil belajarnya kurang lebih sama saja seperti luring". (MH, 28 April 2021)

"Penerapan daring ini memang agak susah dipahami, jadi siswa harus benar-benar membaca buku dan melihat tutorial youtube dengan baik agar bisa mengukur sudut dengan busur derajat dengan benar". (I, 27 April 2021

"Jika anak yang memiliki kemampuan di atas rata-rata cepat memahami materi pengukuran sudut, sedangkan anak yang memiliki daya serap rendah guru harus sabar membimbing. Sehingga ibu membuat kelompok yang dekat rumahnya jadinya bimbingan tutor sebaya. Orang tua juga disini kooperatifmembantu siswa". (SK, 28 April 2021)

\section{Faktor Pendukung dan Penghambat Implementasi Pembelajaran Jarak Jauh (Daring) Dalam Mata Pelajaran Matematika Materi Pengukuran Sudut}

Faktor pendukung dalam penerapan suatu pembelajaran sangatlah berperan besar untuk mencapai keberhasilan pembelajaran daring. Faktor pendukung dalam menerapkan pembelajaran daring pada siswa kelas IV SDN 007 Sungai Kunjang yaitu siswa memiliki handphone sendiri dan kuota internet. Sedangkan faktor penghambatnya yaitu siswa tidak memiliki handphone atau harus bergantian dengan orang tuanya dan kehabisan kuota internet saat pembelajaran daring sedang berlangsung.

"Faktor pendukung dalam menerapkan pembelajaran daring yaitu siswa memiliki handphone dan faktor penghambatnya tidak punya handphone, ini mungkin dikarenakan orang tua siswa tidak mampu untuk membelikan anaknya handphone. Tetapi hal ini biasanya dapat teratas". (MH, 28 April 2021)

"Faktor pendukungnya adalah siswa memiliki handphone sendiri sehingga dapat mengikuti pembelajaran setiap hari dan mengumpulkan tugas tepat waktu. Faktor penghambatnya adalah siswa kehabisan kuota internet dan siswa tidak memiliki handphone sehingga siswa harus mendatangi guru di sekolah untuk menanyakan tugas-tugas apa saja yang harus dikerjakan serta siswa yang handphonenya gabung dengan orang tua sehingga terlambat mengumpulkan tugas". (I, 27 April 2021)

"Faktor pendukungnya yaitu ada gawai dan kuota internet. Tidak ada hambatan dalam menerapkan pembelajaran daring di kelas ibu".(SK, 28 April 2021)

Penerapan pembelajaran daring pada mata pelajaran matematika memiliki kesulitan tersendiri dibandingkan mata pelajaran lainnya (Delyana, 2015). Matematika sering dianggap sebagai pelajaran yang sulit dan rumit karena berhubungan dengan angka, rumus, dan menghitung. Belajar matematika akan lebih mudah jika siswa belajar secara langsung ke guru sehingga mudah memahami materi. Masa pandemi ini mengharuskan siswa belajar matematika melalui daring. 
"Ada sedikit kesulitan dalam menerapkan pembelajaran daring pada mata pelajaran matematika, karena biasanya matematika harus diajarkan melalui papan tulis sehingga siswa lebih mudah memahaminya. Untuk daring ini, harus menggunakan aplikasi tambahan agar tampak sama seperti papan tulis. Karena jika hanya diberi soal-soal saja maka pastinya siswa tidak akan memahami materinya. Matematika memang sedikit lebih rumit. Tetapi selagi siswa memang mau belajar dengan sungguh-sungguh maka akan dapat teratasi". (MH, 28 April 2021)

"Penerapan mata pelajaran matematika ini memang memiliki kesulitan tersendiri dibandingkan dengan mata pelajaran lain yang biasanya menggunakan nalar. Dalam matematika siswa harus menguasai rumus-rumus dan cara melaksanakannya. Memang lebih mudah mengajarkan matematika tatap muka dibandingkan dengan daring. Kebanyakan jika lewat daring ini, banyak siswa yang kurang paham, sebagian juga ada yang paham. Jika soalnya mudah mereka bisa menjawab sedangkan jika diberi soal yang agak susah maka mereka kesulitan untuk menjawabnya". (I, 27 April 2021)."

"Cara mengajarkan matematika lebih rumit dibandingkan mata pelajaran lainnya. Kalau mata pelajaran lainnya itu kami menjelaskan saja siswa bisa langsung paham sedangkan kalau matematika banyak rumus, ada sistematikanya. Pembelajaran matematika melalui zoom dan materi dirangkum". (SK, 28 April 2021)

Penerapan pembelajaran daring di kelas IV secara keseluruhan tidak memiliki kendala dalam penggunaan alat yang mendukung pembelajaran daring (handphone) dan juga tidak memiliki kendala dalam menggunakan media (aplikasi). Kendala yang dialami dalam menerapkan pembelajaran daring ini adalah dalam penggunaan fasilitas yang mendukung pembelajaran daring yaitu tidak memiliki kuota internet karena keterbatasan ekonomi orang tua siswa dan gangguan sinyal.

"Kendala tentu saja ada seperti tidak punya kuota internet dan juga gangguan sinyal karena terkadang sinyal tidak stabil apalagi jika cuaca tidak mendukung (hujan lebat) bisa membuat sinyal terganggu". (MH, 28 April 2021)

"Ada kendala yaitu siswa tidak memiliki atau kehabisan kuota internet sehingga siswa tidak dapat mengikuti pembelajaran ataupun tidak mengumpulkan tugas tepat waktu." (I, 27 April 2021)

"Kendala dalam fasilitas sebenarnya hanya keterbatasan siswa dalam kuota internet jadi terkadang orang tua siswa ada yang mengeluh karena tidak mampu membeli kuota internet terus-menerus." (SK, 28 April 2021)

Suatu pembelajaran jika dijalankan akan bermungkinan mengalami suatu kendala walaupun sedikit. Kendala dalam pembelajaran ini dapat dirasakan oleh guru maupun siswa itu sendiri. Pembelajaran daring ini tentunya memiliki beberapa kendala. Pada materi pengukuran sudut ini guru mengalami kendala dalam mengajarkan siswa untuk mempraktekkan cara mengukur sudut yang benar dan siswa ketika pembelajaran berlangsung tidak dapat mempraktekkan dikarenakan ada yang belum mempunyai penggaris busur derajat dan juga tidak keseluruhan siswa bisa mengikuti video call karena tidak memiliki handphone. 
"Kendala yang saya alami dalam menggunakan alat peraga (busur) yang biasanya saya ajarkan ke siswa melalui papan tulis, dikarenakan harus daring sehingga saya harus mengajarkan melalui video call whatsapp. Sedangkan tidak semua siswa bisa mengikuti video call dikarenakan ada yang tidak memiliki handphone." (MH, 28 April 2021)

"Siswa belum membeli penggaris busur derajat untuk mengukur sudut, sehingga siswa pada hari pembelajaran tidak dapat mempraktekkan secara langsung bagaimana cara menggunakan busur derajat yang benar". (I, 27 April 2021)

"Kendalanya yaitu cara mengepaskan garis-garis busur (SK, 28 April 2021)."

Kendala lain yang umumnya dialami oleh guru dalam melaksanakan pembelajaran daring adalah siswa tidak memiliki handphone sehingga menunggu orang tua pulang kerja sehingga baru dapat belajar, bergantian handphone dengan saudara, tidak mengumpulkan tugas tepat waktu, banyak tugas yang terlewat yang seharusnya dikerjakan sehingga menumpuk (terlambat materi), gangguan sinyal, dan kehabisan kuota internet.

Solusi dari guru yang dapat diberikan kepada siswa jika siswa tidak dapat menggunakan media (aplikasi) dalam pembelajaran adalah hadir ke sekolah untuk menemui guru kelas agar memudahkan siswa untuk tetap belajar.

"Solusi yang dapat diberikan kepada siswa yaitu jika benar-benar siswa tidak bisa menggunakan aplikasi tersebut sebenarnya bisa saja datang ke sekolah menemui saya jika hanya 1-2 orang saja, yang penting artinya tidak membuat kerumunan dan menaati protokol kesehatan. Dari pihak sekolah pun tidak apa-apa. Memang itu solusi yang terbaik dari kami guru untuk siswa. Dari kebijaksanaan kami ini, siswa dapat menghubungi guru wali kelasnya lewat whatsapp atau sms mengenai kendala penggunaan aplikasi tersebut. Kami akan mengajarkan penggunaan aplikasi tersebut dengan baik sampai siswa paham". (MH, 28 April 2021)

"Saya menghubungi siswa untuk menemui saya di sekolah untuk memudahkan mereka juga untuk tetap bisa belajar". (I, 27 April 2021)

Pembelajaran daring tak terlepas dari kendala sinyal yang buruk saat pembelajaran sedang berlangsung. Solusi yang diberikan oleh guru jika gangguan sinyal adalah memaklumi siswa dan tetap harus menyelesaikan tugas yang diberikan meskipun dalam pembelajaran mereka tidak dapat hadir karena gangguan sinyal.

"Solusi yang dapat diberikan kepada siswa yaitu bisa melalui grup whatsapp dan diberikan tugas oleh guru. Karena memang terkadang video call atau zoom terputus-putus videonya karena gangguan sinyal. Jadi kami bisa memaklumi dan tidak bisa memaksakan siswa agar tetap dalam video call atau zoom. Hal terpenting adalah siswa tetap dapat mengerjakan tugas-tugas yang diberikan oleh guru". (MH, 28 April 2021)

"Sebagai guru kami harus memahami keadaan siswa itu sendiri di masa pandemi seperti ini yang terpenting bagi saya siswa tetap harus mengerjakan tugas yang diberikan". (I, 27 April 2021) 
"Solusi dari saya yaitu memakluminya dan saat ujian misalnya terjadi gangguan seperti handphone siswa tidak support dalam menggunakan google form siswa ibu suruh untuk datang ke rumah ibu atau ke sekolah saja untuk mengerjakan ujian menggunakan handphone ibu". (SK, 28 April 2021)

Saat pembelajaran daring telah diterapkan, beberapa siswa tidak aktif dalam pembelajaran. Solusi dari guru kelas jika mengalami hal ini adalah menghubungi siswa yang tidak aktif tersebut atau orang tua siswa dan menanyakan apa saja kendala yang dialami agar bisa ditemukan jalan keluar yang terbaik untuk siswa itu sendiri agar untuk waktu seterusnya siswa dapat melaksanakan pembelajaran secara terus-menerus dan dapat mengerjakan tugas yang diberikan oleh guru.

"Solusi yang dapat diberikan kepada siswa yaitu kami menghubungi siswa yang tidak aktif belajar tersebut dan menanyakan apa saja kendalanya. Apakah tidak mau mengerjakan tugas atau memang ada kendala yang memberatkan siswa dalam menerapkan pembelajaran matematika secara daring ini. Saya biasa menghubungi orang tua siswa melalui whatsapp karena rata-rata sudah mempunyai whatsapp". (MH, 28 April 2021)

"Solusi yang biasa saya lakukan adalah menghubungi siswa atau orang tua siswa lewat whatsapp dan menanyakan apa kendala yang dialami oleh siswa sehingga tidak dapat hadir dalam pembelajaran daring ini".(I, 27 April 2021)

"Solusi dari ibu yaitu menghubungi siswa itu atau orang tua siswa agar siswa dapat kembali aktifbelajar". (SK, 28 April 2021)

Siswa dalam melaksanakan suatu pembelajaran daring khususnya pada pembelajaran matematika tentunya tidak keseluruhan hasil belajarnya telah mencapai KKM sehingga solusi yang dapat diberikan oleh guru adalah perbaikan nilai dan menelusuri apa saja hal yang membuat siswa kesulitan dalam melaksanakan tugas yang diberikan dan memberikan pemahaman kembali kepada siswa agar dapat mengerjakan tugas dengan hasil yang lebih baik lagi.

"Solusi yang dapat diberikan kepada siswa yaitu perbaikan. Jadi siswa-siswa mana yang tidak memenuhi KKM dalam pembelajaran matematika harus melaksanakan perbaikan. Guru harus aktif dalam menghubungi siswa agar kami tau apa masalah dari siswa tersebut sehingga sampai tidak memenuhi KKM. Guru harus membuat siswa nilainya di atas KKM". (MH, 28 April 2021)

"Dikarenakan ini daring, hanya beberapa siswa saja yang benar-benar nilainya rendah diberikan remedial dan pembelajaran tambahan untuk melengkapi kekurangan yang ada. Untuk yang nilainya kurang diberikan pemahaman lagi agar memaksimalkan pemahaman siswa". (I, 27 April 2021)

“Solusi dari ibu yaitu remedial agar nilai siswa memenuhi KKM". (SK, 28 April 2021)

Pembelajaran daring dengan kendala yang dialami siswa membuat beberapa siswa tidak mengumpulkan tugas baik itu terlambat mengumpulkan dengan kurun waktu sebentar ataupun lama sehingga membuat pekerjaan menumpuk. Dalam menghadapi siswa yang 
tidak mengumpulkan tugas, guru memberikan solusi berupa menghubungi siswa yang bersangkutan, memberikan daftar nama-nama siswa yang tidak mengerjakan tugas untuk mengingatkan kembali di grup whatsapp dan menanyakan kesulitan apa yang dialami siswa sehingga tidak mengerjakan tugas dan menyuruh siswa agar segera menyelesaikan tugastugas yang belum dikerjakan.

"Solusi yang dapat diberikan kepada siswa yaitu memberikan list nama-nama siswa di grup
whatsapp yang belum mengerjakan tugas dan siswa tersebut harus memberikan alasan mengapa
belum mengerjakan tugas. Jika sudah sering diingatkan tetapi tidak ada kepedulian siswa
mengerjakan tugas juga maka kami harus sesuai dengan peraturan yang berlaku, kami harus
membangun komunikasi yang baik dengan orang tuanya". (MH, 28 April 2021)

"Solusinya adalah menghubungi siswa yang bersangkutan dan menanyakan kesulitan apa yang dirasakan oleh siswa sehingga tidak dapat mengumpulkan tugas serta saya menyuruh siswa untuk segera mengerjakan tugas agar ada nilai yang dapat dimasukkan ke daftar nilai. Karena sebenarnya jika siswa itu tidak mengerjakan tugas maka siswa itu sendiri yang merugi". (I, 27 April 2021)

"Solusi dari ibu yaitu rajin menghubungi siswa ataupun orang tua siswa agar dapat segera mengumpulkan tugas". (SK, 28 April 2021)

\section{Diskusi}

\section{Implementasi Pembelajaran Jarak Jauh (Daring) dalam Mata Pelajaran Matematika Materi Pengukuran Sudut}

Pembelajaran daring selama pandemi ini merupakan pembelajaran yang paling efektif yang dapat dilakukan oleh sekolah untuk meminimalisir penyebaran covid-19 (Rahmawati et al., 2020; Vortunata et al., 2020). Penerapan pembelajaran daring di SDN 007 Sungai Kunjang telah sesuai dengan ketentuan prosedur standar pendidikan yang berlaku. Persiapan guru dalam melaksanakan pembelajaran daring sudah baik dengan persiapan berupa membuat RPP terlebih dahulu, menentukan jenis media (aplikasi) yang sesuai untuk materi yang akan diajarkan, membuat pembelajaran yang terencana dengan penyampaian materi secara jelas dan singkat dikarenakan keterbatasan waktu dan kuota internet, menyiapkan tugas yang harus dikerjakan siswa dengan batas waktu pengumpulan, memberikan siswa kesempatan untuk selalu bertanya setelah penyampaian materi jika ada hal yang dirasakan sulit oleh siswa serta mengikuti kegiatan pelatihan untuk mendukung keterampilan guru dalam pembelajaran daring.

Pembelajaran daring pada mata pelajaran matematika materi pengukuran sudut ini sudah cukup efektif dirasakan oleh para guru kelas IV. Pembelajaran daring pada materi pengukuran sudut ini dilaksanakan dengan menggunakan media (aplikasi) whatsapp, google meet, google classroom, google form, dan youtube untuk mendukung pemahaman materi pengukuran sudut pada siswa. Media (aplikasi) yang digunakan tersebut dirasakan oleh guru sudah sesuai untuk menerapkan materi pengukuran sudut. Penerapan pembelajaran daring pada materi pengukuran sudut ini berbeda-beda antar kelas tergantung dari kebijakan guru kelas itu sendiri. Pelaksanaan pembelajaran daring ada yang berupa video pembelajaran yang dibagikan di whatsapp, video call, dan melalui google meet. Setelah pembagian video 
pembelajaran atau penjelasan materi telah dijelaskan oleh guru, siswa diberikan tugas materi pengukuran sudut. Keaktifan siswa dalam pembelajaran daring sudah sangat baik, siswa tidak segan untuk bertanya kepada guru jika ada kesulitan. Para siswa juga tidak kesulitan dalam penggunaan aplikasi pendukung pembelajaran. Penilaian guru tidak hanya dari pengumpulan tugas saja, tetapi juga keaktifan dan sikap disiplin siswa. Bagi siswa yang nilainya di bawah KKM maka guru akan mengarahkan siswa untuk melaksanakan perbaikan nilai (remedial).

Penerapan pembelajaran daring dalam materi pengukuran sudut tidak membuat semua siswa secara keseluruhan memahami cara mengukur sudut dengan benar. Beberapa siswa kesulitan dalam mengepaskan garis-garis di busur sehingga tidak mengetahui besarnya derajat pada sudut. Siswa yang daya serapnya tinggi sangat mudah untuk memahami materi pengukuran sudut ini dan sebaliknya dengan siswa yang daya serapnya kurang maka siswa cukup kesulitan untuk memahami dan mempraktekkan cara mengukur sudut yang benar. Tetapi walaupun siswa kesulitan, mereka tidak segan untuk terus bertanya kepada guru sampai memahami materi dengan baik.

\section{Faktor Pendukung dan Faktor Penghambat Penerapan Pembelajaran Daring Dalam Mata Pelajaran Matematika Materi Pengukuran Sudut}

Faktor pendukung dari pembelajaran daring ini yaitu siswa memiliki handphone sendiri dan kuota internet serta rasa semangat belajar matematika dari siswa itu sendiri. Pelaksanaan pembelajaran daring ini tidak memberatkan siswa, siswa boleh langsung bertemu dengan guru jika tidak memiliki handphone karena guru dengan senang hati dapat menjelaskan langsung tetapi dibatasi jumlah siswa yang datang agar tidak terjadi kerumunan. Untuk pengumpulan tugasnya, siswa datang secara langsung ke sekolah untuk menemui guru. Bagi siswa yang lambat mengumpulkan tugas maka harus memberikan keterangan langsung kepada guru. Guru selalu aktif mencari informasi kepada siswa atau orang tua siswa yang tidak hadir ataupun jarang hadir dalam pembelajaran daring.

Faktor penghambat dari pembelajaran daring ini adalah siswa tidak memiliki handphone sendiri atau harus bergantian dengan orang tua atau saudara dan kehabisan kuota internet saat pembelajaran daring sedang berlangsung. Hal ini dapat dimaklumi oleh para guru dikarenakan kondisi pandemi saat ini. Meskipun beberapa siswa tidak dapat mengikuti pembelajaran dikarenakan tidak memiliki handphone ataupun kuota internet, siswa tetap harus mengerjakan tugas yang telah diberikan oleh guru.

Mata pelajaran matematika dirasakan oleh guru sedikit rumit dalam pengajaran materi dibandingkan mata pelajaran lainnya (Winarso, 2014). Siswa yang memiliki daya serap pemahaman yang baik maka mudah saja bagi siswa tersebut untuk mengerjakan tugas yang diberikan oleh guru dan begitu sebaliknya dengan siswa yang kurang cepat atau lambat dalam pemahaman materi yang disampaikan oleh guru maka dari itu guru harus lebih dalam dan lebih luas untuk mengajarkan materi. Guru harus selalu memberikan kesempatan dan kebebasan pada siswa untuk selalu bertanya melalui whatsapp jika dirasa ada yang masih belum dipahami. 
Pembelajaran daring yang diterapkan di masa pandemi ini tentunya memiliki beberapa kendala baik yang dialami oleh guru maupun siswa itu sendiri. Kendala umumnya yang sering dialami oleh guru adalah siswa tidak mengikuti pembelajaran dikarenakan tidak memiliki handphone ataupun bergantian handphone dengan saudara dan orang tua sehingga tidak bisa melihat penjelasan secara langsung oleh guru, siswa kehabisan kuota internet, siswa terlambat mengumpulkan tugas dengan kurun waktu yang cukup lama, dan keterlambatan siswa dalam memahami materi (Syarifudin, 2020).

Pembelajaran daring yang diterapkan pada materi pengukuran sudut ini para guru mengalami beberapa kendala seperti dalam mengajarkan secara langsung melalui video call sinyal tiba-tiba terputus dan tersendat sehingga guru harus mengulang penjelasan kembali agar siswa bisa memahami serta siswa yang tidak memiliki handphone harus lebih mandiri belajar matematika agar tidak mengalami keterlambatan dengan teman-temannya (Yantoro et al., 2021). Kendala guru dalam mengajarkan materi pengukuran sudut ini yaitu siswa agak sulit mengepaskan garis-garis di busur derajat sehingga tidak mengetahui secara pasti besar derajat yang diukur dan juga saat pembelajaran materi pengukuran sudut berlangsung ada beberapa siswa yang tidak membeli atau mempunyai busur derajat sehingga siswa tidak bisa mempraktekkan cara mengukur sudut menggunakan busur derajat.

Pelaksanaan pembelajaran daring ini secara keseluruhan tidak memiliki kendala dalam penggunaan alat yang mendukung pembelajaran daring (handphone) dan juga tidak memiliki kendala dalam menggunakan media (aplikasi). Kendala yang dialami dalam menerapkan pembelajaran daring ini adalah dalam penggunaan fasilitas yang mendukung pembelajaran daring yaitu tidak memiliki kuota internet karena keterbatasan ekonomi orang tua siswa dan gangguan sinyal. Hal ini tidak terlalu berpengaruh besar dalam pembelajaran karena hal ini dapat dimaklumi oleh guru yang terpenting siswa tetap mengerjakan tugas dengan baik. Jika ada siswa yang kesulitan dalam penggunaan media (aplikasi) guru memberikan solusi dengan mendatangi guru ke sekolah agar memudahkan siswa untuk tetap belajar.

Kekurangan pembelajaran daring yang paling sering terjadi adalah gangguan sinyal internet. Hal ini membuat beberapa siswa tidak dapat mengikuti pembelajaran. Adanya gangguan sinyal ini guru memberikan solusi kepada siswa agar tidak memaksakan tetap mengikuti pembelajaran dikarenakan video pembelajaran tidak dapat diputar atau video call pasti akan terputus-putus. Guru cukup dengan memerintahkan siswa untuk mengerjakan tugas saja dengan waktu yang telah ditetapkan oleh guru. Saat pembelajaran berlangsung, terkadang ada beberapa siswa yang tidak aktif mengikuti pembelajaran. Hal ini membuat guru harus selalu aktif menghubungi siswa dan menanyakan kendala-kendala yang dialami siswa sehingga tidak dapat mengikuti pembelajaran.

Pembelajaran matematika memang cukup sulit dirasakan oleh sebagian siswa. Hal ini membuat beberapa siswa nilainya tidak mencapai KKM. Guru memberikan solusi berupa perbaikan nilai atau remedial dan menelusuri apa saja hal yang membuat siswa kesulitan dalam melaksanakan tugas yang diberikan dan memberikan pemahaman kembali kepada siswa agar dapat mengerjakan tugas dengan hasil yang lebih baik lagi. Kendala lain yang sering dialami guru adalah beberapa siswa tidak mengumpulkan tugas dalam kurun waktu 
yang lama, dengan hal ini guru memberikan solusi berupa menghubungi siswa yang bersangkutan, memberikan daftar nama-nama siswa yang tidak mengerjakan tugas untuk mengingatkan kembali di grup whatsapp dan menanyakan kesulitan apa yang dialami siswa sehingga tidak mengerjakan tugas dan menyuruh siswa agar segera menyelesaikan tugastugas yang belum dikerjakan. Selama pembelajaran daring guru diwajibkan harus aktif memantau pekerjaan siswa dan selalu aktif menghubungi siswa yang tidak mengumpulkan tugas dan sering tidak menghadiri pembelajaran.

\section{Kesimpulan}

Berdasarkan hasil penelitian yang telah dilakukan dapat disimpulkan bahwa pembelajaran daring yang diterapkan dalam pandemi covid-19 ini dalam pembelajaran matematika materi pengukuran sudut tidak secara keseluruhan efektif, hal ini dikarenakan beberapa siswa tidak bisa memami materi dengan baik dan tidak dapat mengukur sudut dengan benar. Kendala yang sering terjadi dalam pembelajaran daring ini membuat pembelajaran tidak sepenuhnya efektif namun dengan adanya solusi yang baik dari guru maka kendala dapat diminimalisir dengan baik sehingga pembelajaran daring dapat tetap berjalan. Aplikasi yang digunakan oleh guru sudah sesuai dengan materi yang akan diajarkan. Guru telah melakukan persiapan menghadapi pembelajaran daring dengan baik dan selalu menyediakan solusi untuk siswa yang mengalami kendala dalam melaksanakan pembelajaran daring.

\section{Referensi}

Arif, T. A., \& Iskandar, I. (2018). TEKNIK PENYUSUNAN BAHAN AJAR BAHASA INDONESIA BAGI GURU DI SEKOLAH DASAR. Prosiding Seminar Nasional Pendidikan, 1(1). https://jurnal.umj.ac.id/index.php/SNP/article/view/2802

Delyana, H. (Hafizah). (2015). Peningkatan Kemampuan Pemecahan Masalah Matematika Siswa Kelas VII Melalui Penerapan Pendekatan Open Ended. Lemma, 2(1), 144859. https://doi.org/10.22202/JL.2015.V2I1.523

Mustakim, M. (2020). EFEKTIVITAS PEMBELAJARAN DARING MENGGUNAKAN MEDIA ONLINE SELAMA PANDEMI COVID-19 PADA MATA PELAJARAN MATEMATIKA. Al Asma: Journal of Islamic Education, 2(1), 1. https://doi.org/10.24252/asma.v2i1.13646

Novitasari, D. (2016). PENGARUH PENGGUNAAN MULTIMEDIA INTERAKTIF TERHADAP KEMAMPUAN PEMAHAMAN KONSEP MATEMATIS SISWA. FIBONACCI: Jurnal Pendidikan Matematika Dan Matematika, 2(2), 8-18. https://jurnal.umj.ac.id/index.php/fbc/article/view/1650

Rahmawati, N. R., Rosida, F. E., \& Kholidin, F. I. (2020). ANALISIS PEMBELAJARAN DARING SAAT PANDEMI DI MADRASAH IBTIDAIYAH. SITTAH: Journal of Primary Education, 1(2), 139-148. https:/ / doi.org/10.30762/SITTAH.V1I2.2487

Safitri, D. (2019). Pengaruh Model Pembelajaran TGT (Team Game Tournament) terhadap hasil belajar matematika siswa kelas IV SDN 1 Pakuan Aji Tahun Pelajaran 2019/2020. IAIN Metro. 
Sugiyono. (2017). Metode Penelitian Kuantitatif, Kualitatif, dan RED. Alfabeta. https://www.google.co.id/books/edition/Metode_Penelitian_Pendidikan/uTb MDwAAQBAJ?hl=id\&gbpv=1\&dq=sugiyono+metode+penelitian + kuantitatif $+\mathrm{k}$ ualitatif + dan $+r \% 26 \mathrm{~d} \&$ printsec $=$ frontcover

Syarifudin, A. S. (2020). IMPELEMENTASI PEMBELAJARAN DARING UNTUK MENINGKATKAN MUTU PENDIDIKAN SEBAGAI DAMPAK DITERAPKANNYA SOCIAL DISTANCING. Jurnal Pendidikan Bahasa Dan Sastra Indonesia Metalingua, 5(1), 31-34. https://doi.org/10.21107/METALINGUA.V5I1.7072

Vortunata, V., Ustoyo, A., Sholikhah, M., \& Zuhro, L. (2020). IMPLEMENTASI PEMBELAJARAN DARING DI SEKOLAH DASAR ISLAM DALAM MASA PANDEMI COVID-19. Jurnal DIDIKA: Wahana Ilmiah Pendidikan Dasar, 6(2), 261271. https:// doi.org/10.29408/DIDIKA.V6I2.2725

Winarso, W. (2014). Membangun Kemampuan Berfikir Matematika Tingkat Tinggi Melalui Pendekatan Induktif, Deduktif Dan Induktif-Deduktif Dalam Pembelajaran Matematika. Eduma: Mathematics Education Learning and Teaching, 3(2), 56259. https:// doi.org/10.24235/eduma.v3i2.58

Wiratman, A., Mustaji, M., \& Widodo, W. (2019). The effect of activity sheet based on outdoor learning on student's science process skills. Journal of Physics: Conference Series, 1157(2), 022007. https:/ / doi.org/10.1088/1742-6596/1157/2/022007

Wiratman, Arwan, Widiyanto, B., \& Fadli, M. (2021). Analisis Keterampilan Proses Sains Peserta Didik Madrasah Ibtidaiyah pada Masa Pandemi Covid-19. Bidayatuna: Jurnal Pendidikan Guru Madrasah Ibtidaiyah, 4(2), 185-197. https:// doi.org/10.36835/BIDAYATUNA.V4I1.948

Yantoro, Y., Hayati, S., \& Rahmad, R. (2021). STRATEGI PENILAIAN PEMBELAJARAN MATEMATIKA PADA MASA PANDEMI COVID-19 DI KELAS TINGGI SEKOLAH DASAR. Jurnal Fundadikdas (Fundamental Pendidikan Dasar), 4(1), 21-31. https://doi.org/10.12928/FUNDADIKDAS.V4I1.3657 